\title{
The Intension of Students' Entrepreneurship in State Polytechnic of Padang
}

\author{
Rusmadi \\ State Polytechnic Padang, State University of Padang, Indonesia \\ E-mail: rusmadi-madi@gmail.com \\ DOI: http://dx.doi.org/10.15548/jt.v21 i2.89
}

\begin{abstract}
The objectives of this research were to identify the relationship between entrepreneur intention (Y) and information of entrepreneur intention $\left(\mathrm{X}_{1}\right)$, model of parents' guidance to entrepreneur intention $\left(\mathrm{X}_{2}\right)$, and the attitude of entrepreneur cooperation to entrepreneur intention $\left(\mathrm{X}_{3}\right)$ in them. Besides, the study also seeks the correlation between information of entrepreneur intention $\left(\mathrm{X}_{1}\right)$, model of parents' guidance to entrepreneur intention $\left(\mathrm{X}_{2}\right)$, and attitude of entrepreneur intention $\left(\mathrm{X}_{3}\right)$. Questionnaires were used to investigate the model of parents' guidance, and attitude of entrepreneur cooperation to entrepreneur intention. The result showed that there were significant linear regression of entrepreneur information to entrepreneur intention (26,7\%) and significant linear correlation among variables that are information, model of parents' guidance, and attitude of entrepreneur cooperation with entrepreneur intention $(5,8 \%)$.
\end{abstract}

Key Words: Behavior, parents' guidance, information, intention, students' attitude.

\section{INTRODUCTION}

The increasing number of unemployment in the country has been caused by several factors such as lack of information and training. Current job market does not seem to give a clear picture of special conditions required in a particular job or income. The educational institutions and training get difficulties in preparing appropriate curriculum and materials that are relevant to the needs and conditions of employment. The following figure shows the data on the number of unemployment by level of education (Graph 1).

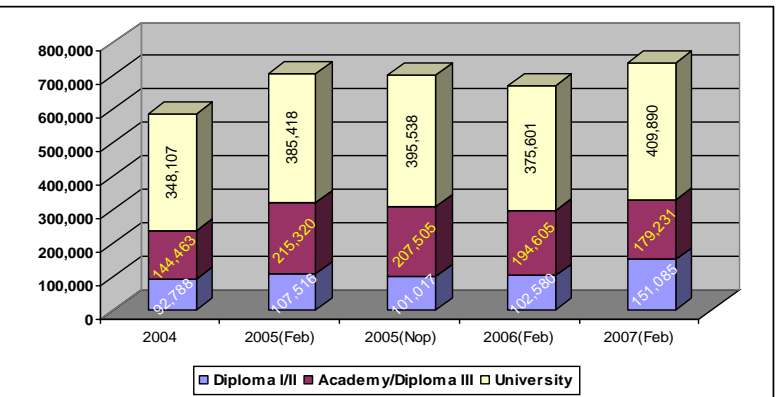

Figure 1. The number of unemployment by level of education
From this graph, it appears that colleges including the Diploma program, showed a high rate. One cause of unemployment is the lack of independence of the college graduates to become civil servants or looking for job.

Labor is a huge potential in the development of work and is closely related to the skill level, number and population growth, the state of the job market, and the mental attitude or college diploma in either general or vocational. Data from the Central Statistics Agency in West Sumatra (2008) from 2003 to 2008 estimated population growth of $2.16 \%$ per year and the growth of the labor force is expected to increase $2.78 \%$ per year, meaning that the growth of the labor force is higher than the population growth.

The studies conducted by the Directorate of Research and Community Service Directorate General of Higher Education Ministry of National Education of Indonesia (2009), showed that universities produced more graduates than workers. Although they were highly educated entrepreneurs, they did not master science and technology so that they failed to be independent in the society. The fact that several young 
scholars who successfully established creative industry or company and being capable of producing a commodity product, was not the result of entrepreneurship attitude which were developed in formal education.

The existence of current phenomenon in the field showed that approximately among 34 million small businesses in Indonesia, there were only 3 to $5 \%$ occupied by highly educated, while less than $2 \%$ of them graduated from diploma(Polytechnic), and 75 to $85 \%$ graduated from Elementary School (SD). According to Rusmardi (2003), there is still a little educated persons who deliberately falls on a small scale entrepreneurship, but lack capabilities (skills) in the sector of Small and Medium Enterprises (SMEs) makes them remain in small business.

Vocational education as 'roommatesorganized educational programs' are directly related to the preparation of individuals for a career requiring other than a baccalaureate or advanced degree (Evan and Lang, 2006). Based on the data management information system (MIS) in Padang State Polytechnic (2009) that among 8076 graduates, there were 3,596 people registered as job seekers $(49.93 \%)$ while the rest had found their safety works (50.07\%). Judging from the fields of Padang State Polytechnic Alumni, it turns out more graduates who work in the field of industry and selfemployment than working as a government employee, with a ratio of $65.43 \%: 34.57 \%$ (LAKIP in State Polytechnic of Padang, 2009) .

Research on entrepreneurship should be preceded by the entrepreneurial process such as what needs to be done to become an entrepreneur. Entrepreneurship research should be directed to a business activity based on creative and innovative ideas with personal characteristics to the challenge, having selfconfidence, motivation into the future and have the skills to meet the needs in a process to produce the services / products were different than the existing and able to satisfy consumers (Gartne, 1989). To realize an entrepreneur character, one must accept the logical consequences of such a saying in Minangkabau culture "kasawah baluluak-luluak, bajariah manantang buliah, barugi mangko balabo, nak kayo amuah karajo, rajin baraja mako kapandai, pasa jalan dek batampuah, hapa kaji dek baulang" means that an entrepreneurial must be sincere and ready to accept the fact of life if he or she wants to be success. Because success requires outer and inner toughness to face any challenge armed with knowledge and skills.

There are several factors that affect entrepreneurship, among others are the nature of interest, the nature of information, the nature of parenting, and the nature of attitudes.

\section{The Nature of Interest}

Individual interest to do something is a function of attitudes and norms that influences the behavior in specific situations and motivation in these norms. The influence of these two components is expressed by Ajzen et $a l,(1981)$ in theoretical mathematical symbols as follows:

$$
\begin{aligned}
& \mathrm{BI}=(\mathrm{AB}) \mathrm{W} 1+(\mathrm{SN}) \mathrm{W} 2 \\
& \mathrm{~B}=\text { behavior }
\end{aligned}
$$

$\mathrm{I}=$ interest to realize the behavior B

$\mathrm{AB}=$ attitude toward behavior $\mathrm{B}$

$\mathrm{SN}=$ subjective norm component empirical

$\mathrm{W} 1$ and $\mathrm{W} 2$ = weight of each To explain the attitude toward the behavior $(\mathrm{AB})$, is expressed in the following equation:

$$
A_{B}=\sum_{i=1}^{n} b_{1} e_{1}
$$

$b=$ personal evaluation of the magnitude of the belief

$\mathrm{e}=$ that there are consequences to a person 's behavior in his efforts bore $\mathrm{B}$.

$n=$ many groups 
Subjective norm being a contributor to the formation of interest in the behavior described in the following equation :

$$
\mathrm{SN}=\sum_{\mathrm{i}=1}^{\mathrm{n}} \mathrm{b}_{\mathrm{i}} m_{\mathrm{i}}
$$

$\mathrm{Bi}=$ Belief that normative beliefs, one expects that the group or individual behavior

manifested least B.

$\mathrm{mi}=$ motivation to perform behavior $\mathrm{B}$

$\mathrm{n}=$ many groups .

The above equation when associated with someone's entrepreneurship would arise from his attitude towards entrepreneurship and a subjective norm towards entrepreneurship. In this case the attitude towards entrepreneurship which is determined by the components that influence such beliefs would be the consequences if a person has been selfemployed, these consequences include: the adequacy of materials, information, and knowledge a person has to realize the entrepreneurial behavior. Whereas subjective norm here determines the number of groups or individuals who can affect a person such as parents, faculty, leadership and entrepreneurship to realize the intentions driven by their own motivations in entrepreneurship.

For more explanation of the formation of theoretical interest can be outlined in the following scheme:

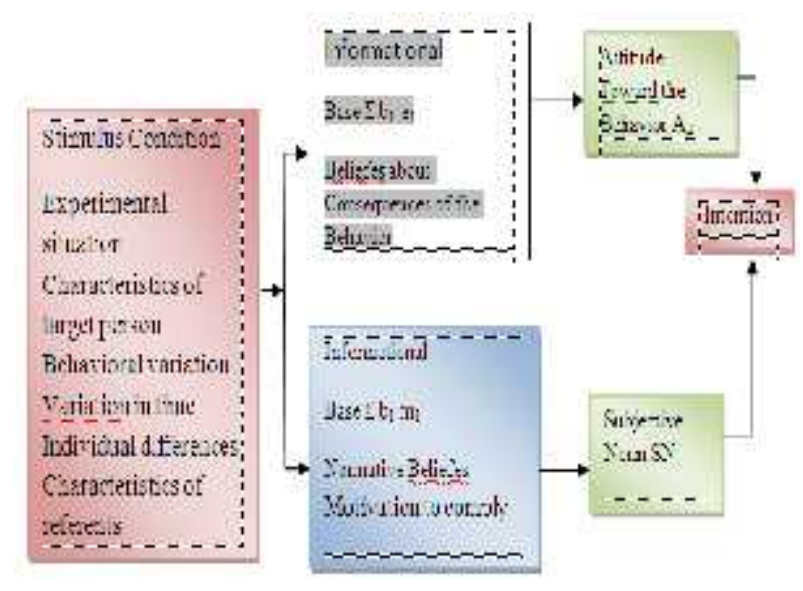

Figure 2. Influences that lead to the formation of interest (Ajzen et. al, 1981)

\section{The Nature of Information}

Radio broadcasts can attract the interest of students because it presents the problems of everyday life which is presented in a fun way, anywhere, anytime, and in any case so that students can listen to it ( Hamalik, 1982). According to Soemanto (1984) the role of the media can lead to activities in the initiation and the development phase in the form of an object, such as an exhibition, carpentrer, animal husbandri, etc. Butarbutar (1987) contends that media proved a lot of things both inside and outside the classroom that can be used as an educational tool. In places where there are limited numbers of teachers, the media has proven its ability to bear most of the tasks of education, especially in the field of adult education and the eradication of illiteracy. In addition, the media is very helpful exercises and techniques as well as industry practices faculty. There is no doubt that the media as educators, textbooks, radio, and films have proved the function of the media. Here is a chart of the Effect of Communication by Schubert:

Figure 3. Chart Effect of Communication

\section{The Nature of Parenting}

Theory is to predict the behavior of the so-called Theory of Reasoned Action. This theory gives the approach in investigating attitudes to predict behavior:

a. The approach moves from the concept of the classical attitude (cognitive, affective, and behavioral) to a new concept of attitude that the affective dimension only. 
b. This approach measures the attitude toward the action as a substitute measure of the object (the object).

c. Of this approach include "interest to do "as the material between intevening behavior.

d. This approach to enter: action, targets, and circumstances in measuring attitudes and interests object to do something.

The details on the above concept relationship, Ajzen et. al. (1975) proposes a model as depicted in the following scheme:

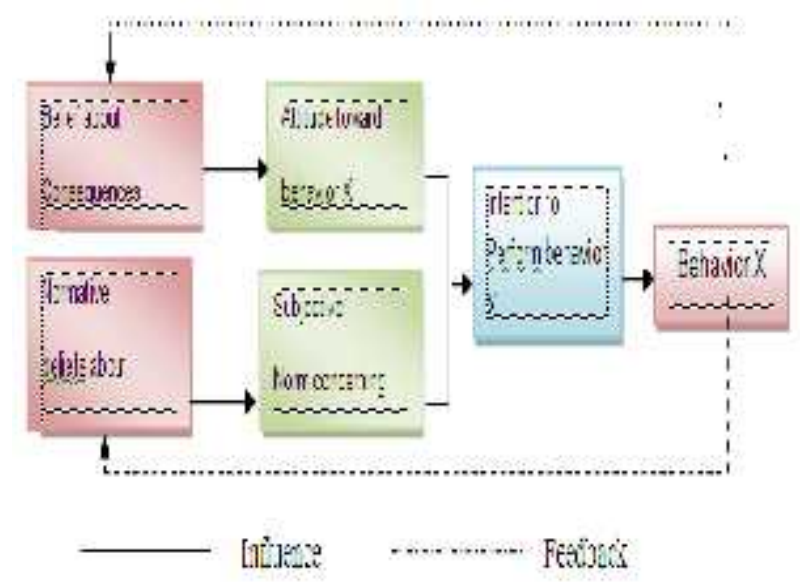

Figure 4. The relationship between knowledge, attitudes, interests and behavior (Ajzenet.al., 1975) .

\section{The Nature of Attitudes}

Dictionary of Drafting Team Development and Language Development Center (1994) is analogous to the opinion of Marbun (1986) who states that entrepreneurs are the ones who have the ability to see, assess opportunities or business opportunities, and able to collect resources (employees, capital, engineering, etc.) is required in order to obtain profits or results, and be able to take appropriate measures to ensure the achievement of success. According to Andrew et. al., (1986) the hallmarks of entrepreneurship are: selfconfidence, task-oriented and results, risktaking, as a leader, originality of the findings, and future oriented.
In line with the meaning of life, the Minangkabau is credited to your family and community, working part likes highly appreciated. Working that allows people to leave something for his nephew. According to Esten (1993) with the results of the work can be avoided : hilang rono dek panyakik, hilang bangso dek indak baemeh. In other words, a person's self-esteem can be lost due to a poor, working so hard is one way to avoid it. In the indigenous philosophy also disclosed :kayu kareh jadian dahan, nan rancak dibuek kalamari, barani bahujan bapaneh, baitu urang mancari rasaki.

Because of this work ethic, young people in the village were told to leave. This hard work ethic serves the foundation for the value of the Minangkabau. According to Naim (1984 ) migration has some basic elements, namely : 1 ) leave home, 2 ) with a will of its own, 3 ) for a long time or not, 4 ) with the goal of earning a living, studying, or looking for experience, 5 ) usually with the intention of returning home, and 6 ) migrated as a social institution is entrenched. This is consistent with the results of the research Nur (2002) that found a home basamo, a social activity that develops in Minangkabau people overrseas. The positive aspect is contained in these activities, in addition to the spirit that continues to be fostered, this activity is able to bring the idea to progress hometown, and even goes along with it, various forms of fund-raising efforts or material successfully realized. However, the attitude of employers Minang in general are such:

- Most do not / less developed, because of the attitude of a quitter.

- Weak management capability.

- Habits like to wander but not equipped with adequate knowledge and skills, only armed with advice alone.

According Soemanto (1984), human being have entrepreneurial that covers:

1. Strong will

2. A strong belief over personal power, in the form of (a) self-control, (b) self- 
confidence, and (c) understanding the goals and needs.

3. Honesty and responsibility in this case is necessary to : (a) high moral and (b) self- discipline .

4. Physical and mental endurance in this regard is necessary : (a) the physical and spiritual health, (b) patience, and (c) patience.

5. Perseverance and tenacity to work hard .

6. Constructive and creative thinking.

\section{METHOD}

Based on the review of related theory studies and relevant research studies, the authors propose the framework as shown below.

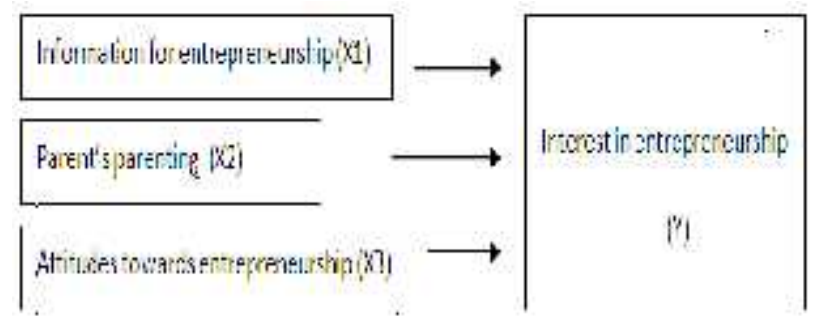

Instruments used in the study were questionnaires. For items that are variable interest in entrepreneurship grain interval variable interest scale obtained through questionnaires using a Likert scale. Questions related to behaviors are implemented in the four elements of action, targets, environment, and time in the form of finding indicators of entrepreneurial ideas, coaching, capital, leadership, and desire to manage place of business.

The validity of the instrument is related to the degree of how far the instrument can perform exactly the functions entrusted to him, and what it means to the instrument prepared (Cronbanch, 1990). The validity of the research is used in the content (content validity). Considerations on the validity of this is due to the need to be investigated that is already known to the respondents and research tool in measuring the ability of content (Sudjana, 2006). To create a content validity according to Gronlund (1982 ) there are several steps that must be taken, namely : (1) identifying the main topic of discussion and behavioral outcomes to be measured, (2) creating a table detailing the specifications of the sample of the questions that will be used, and (3) creating a test that comes closest to the specifications table.

Based on the above, the steps taken to determine the validity of assessment questionnaires are among others :

1. Carefully and systematically examine the suitability of the instrument were arranged with the preparation of the grating, with a view to determine whether each sub- indicator are represented or not in point instrument when it is represented content validity (Arikunto, 1984) .

2. Ask for help experts to examine systematically the contents of the instruments, as well as evaluating the relevance of sub-indicator variables specified item. If the experts who examine the view that the instrument is adequately reflect this region, the instrument can be said to represent the content validity (Ary, 2004) .

Before analysis, the data obtained were tested by using statistical analysis techniques. Furthermore, the new use of hypothesis testing. The normality and linearity tests (through Kolmogorof - Smirnov through SPSS version 15) were used to determine the distribution of research data. Linearity test is aimed at testing whether or not the data are linear and they are associated with $\mathrm{Y}$ between $\mathrm{X} 1, \mathrm{X} 2$ and $\mathrm{Y}, \mathrm{X} 3$ with Y. If the data is normal, then $Y$ scale has continuous distribution, so, $\mathrm{Y}$ must be normal for any price $\mathrm{X}$.

This study uses linear regression analysis. For linear regression analysis of the $Y$ 's price was not in the form of continuous data. When the grain scale continuous variables $\mathrm{X} 1$ each item of this variable should be tested whether or not a linear relationship with grain variable $\mathrm{Y}$. The model used in the analysis of these data is the multiple regression models with the following equation : $\mathrm{Y}=\beta 0+\beta 1 \mathrm{X} 1+$ $\beta 3 \mathrm{X} 3 \beta 2 \mathrm{X} 2$ 


\section{RESEARCH FINDINGS}

Once the process is done for the sake of the process during the study, it is found that the entrepreneurship (X1), parents' guidance (X2), attitudes towards entrepreneurship (X3) significantly affect the interests of entrepreneurs $(\mathrm{Y})$, because the value of the probability is less than .05 . Each $1 \%$ increase in $\mathrm{X} 1$ will increase the value of $\mathrm{Y}$ by $0.185 \%$. Each $1 \%$ increase in $\mathrm{X} 2$ will increase the value of $\mathrm{Y}$ by $0.130 \%$. Each $1 \%$ increase in $\mathrm{X} 3$ will improve the value of Y by $0.145 \%$. Adjusting R - Square of 0.092 indicates that the contribution of independent variables (information on entrepreneurship, parenting parents, and attitudes towards entrepreneurship) on the dependent variable (the interest for entrepreneurship) is $9.2 \%$, while $90.8 \%$ is determined by the contribution from a variety of other factors such as.

1. Information about entrepreneurship (X1) significantly affects the interests of entrepreneurs, in a linear relationship. Information about self-employment contribution of $18.5 \%$, meaning that for every $1 \%$ increase in information about the entrepreneur will be able to increase the interest for entrepreneurship at 0.185 $\%$.

2. Parenting parents (X2) in a linear relationship significantly influence interest in entrepreneurship, in which a linear relationship. Contributions parenting parents by $13 \%$, meaning that for every $1 \%$ increase in information about the entrepreneur will be able to increase the interest for entrepreneurship at $0.130 \%$

3. Attitudes towards entrepreneurship (X3) significantly affect the interests of entrepreneurs, in a linear relationship. Contribution to the entrepreneurial attitude of $14.5 \%$, meaning that for every $1 \%$ increase in information about the entrepreneur will be able to increase the interest for entrepreneurship at 0.145 $\%$.

4. Information about entrepreneurship, parenting parents experienced students in the household, and the attitude of students towards entrepreneurship together - each contributing significantly to the interest to entrepreneurs. Taken together accounted for $9.2 \%$ of the interest in self-employment, while 90.8 $\%$ is determined by the contribution of many other factors.

\section{CONCLUSION}

1. Each educational institution is expected to hold entrepreneurship courses as a source of information to students (students) about various things about entrepreneurship in an effort to increase interest in entrepreneurship.

2. Government as policy makers are expected to play an active role in efforts to increase interest in entrepreneurship and cultivate an entrepreneurial spirit , so the unemployment rate and the number of job seekers is expected to decline.

3. Keep in holding training - training and seminars on entrepreneurship, industrial visits and can show the figure of a successful entrepreneur who has been on an ongoing basis, so as to encourage an interest in entrepreneurship.

4. There needs to be an understanding for those parents that being entrepreneurial is a good thing. The contribution of parenting parents to interest in entrepreneurship necessary to understand the parents to instill entrepreneurial values early on.

\section{REFERENCES}

Ajzen, Icek \& Fishbein, Martin. (1975). Beliefs, Attitude, Intention and Behavior; An Introduction to Theory and Research. New York : Addison - Wesley Publishing Company.

(1981). Understanding Attitude and Predicting Social Behavior : England CliffsnNJ : Prentice Hall . 
Andrews, C. M. (1985). Role of Mass Communication in Development. Yogyakarta: GadjahMada University Press.

Ary, Donald. (2004). Introduction to Research in Education. Translation by :AriefFuchon . London: Student Library.

BPS West Sumatra province . (2008). West Sumatra in the figure. Padang : $B P S$ Sumatera.

Butarbutar, R. (1987). Entrepreneurial intentions of the students for Class III STAN in Medan. Unpublished thesis.Jakarta : Jakarta Teachers' Training College Graduate Program.

Cronbach, L.J. (1946). Response Sets and Test Validity. NewYork : AHM Publishing .

DP2M Director General of Higher Education. 2009. Entrepreneurial Student Guide. Jakarta: Directorate General of Higher Education.

Drafting Team Coaching and Development English Dictionary. (1984). Indonesian dictionary. Jakarta: PT. Scholastic.

Esten ,Mursal. (1993). Minangkabau Tradition and Renewal. Padang :Angkasa Raya .

Evans and Lang. 2006. Models, Strategies, and Methods for Effective Teaching. Boston: Pearson.

Gartner, W.B. (1994). Where's Entrepreneurship ; Finding the Definitive Definition : in G. E , Hills Marketing and
Entrepreneurship, pp. 25-33 . Westport $\mathrm{G}$; Quorum Books .

Gronlund, N. E. (1974). Improving Marking and Reporting in Classroom Instruction. New York : MacMillan Publishing Co. Inc.

Hamalik, O. (1982). Media Education. New York: Alumni.

LAKIP Polytechnic. (2009). Government Performance report Akuntabilitas Padang State Polytechnic. Champaign : Champaign State Polytechnic .

Marbun, B.N. (1976). Small Business Management. Jakarta : Library Development Man Pressindo.

Naim, Muchtar. (1984). Merantau :Minangkabau Voluntary Migration, translation. Yogyakarta :GadjahMada University Press .

Nur, Agustiar Shah. (2002). Indigenous Leadership Credibility penghoeloe in Minangkabau. Bandung: Great Lubuk.

Rusmardi, et.al. (2003). Free Coaching Group Entrepreneurship Diploma Program . P4D.

Sudjana. (2006). Method of Statistics. New York: Tarsito .

Sumanto, Wasty. (1984). Self education. Jakarta : PT. Script Development. 